\title{
PENGARUH NON PERFORMING FINANCING PEMBIAYAAN MUDHARABAH DAN NON PERFORMING FINANCING PEMBIAYAAN MUSYARAKAH TERHADAP PROFITABILITAS PADA BANK UMUM SYARIAH DI INDONESIA
}

\author{
Sri Mulyaningsih \\ Universitas Muhammadiyah Purwokerto \\ Iwan Fakhruddin \\ Universitas Muhammadiyah Purwokerto
}

\begin{abstract}
This study aimed to know the influence of non performing financing in Mudharabah system and non performing financing in musyarakah system toward the profitability of the the Islamic banks. A financing channeled to customers potentially leads to financial problems. Financing problematic in the Islamic banks can be seen from the level of non performing financing. The data used in this study was the secondary data in the form of annual financial report in islamic banks during period 2009 up to 2013.

The method of data analysis used in this research was multipel linier regression analysis. The samples taken were 33 of data includes 8 Islamic banks during the period of 5 years. The samples taken by using the purposive sampling technique. The results showed that simultan eously non performing financing Mudharabah and non performing financing Musyarakah affected on the profitabilty og Islamic banks, while partially non performing financing mudharabah didn't affect negatively, but positively affected financing with the significance 0,018 and non performing financing musyarakah didn't affect the profitability of Islamic banks.
\end{abstract}

Keyword : NPF Mudharabah Financing, NPF Musyarakah Financing, Profitability. 


\section{ABSTRAK}

Penelitian ini bertujuan untuk mengetahui pengaruh pembiayaan bermasalah dalam sistem Mudharabah dan non performing financing (NPF) dalam sistem musyarakah terhadap profitabilitas bank syariah. Sebuah pembiayaan disalurkan kepada nasabah berpotensi menyebabkan masalah keuangan. Pembiayaan bermasalah di bank syariah dapat dilihat dari tingkat pembiayaan bermasalah. Data yang digunakan dalam penelitian ini adalah data sekunder berupa laporan keuangan tahunan bank syariah selama periode 2009 sampai dengan 2013.

Metode analisis data yang digunakan dalam penelitian ini adalah analisis regresi linier multipel. Sampel yang diambil adalah 33 data termasuk 8 bank syariah selama periode 5 tahun. Sampel diambil dengan menggunakan teknik purposive sampling. Hasil penelitian menunjukkan bahwa secara simultan non performing pembiayaan Mudharabah dan Musyarakah, non performing terpengaruh pada profitabilitas bank syariah, sementara sebagian non performing mudharabah pembiayaan tidak mempengaruhi secara negatif, tapi terpengaruh positif pembiayaan dengan signifikansi 0,018 dan non performing musyarakah pembiayaan tidak mempengaruhi profitabilitas bank syariah.

\section{Kata Kunci : NPF Mudharabah Pembiayaan, NPF Musyarakah Pembiayaan, Profitabilitas.}

\section{PENDAHULUAN}

Kehidupan perekonomian di dunia tidak dapat dipisahkan dari dunia perbankan. Jika dihubungkan dengan pendanaan, hampir semua aktivitas perekonomian menggunakan perbankan sebagai lembaga keuangan yang dapat membantu jalannya usaha tersebut. Peran bank dalam hal ini sebagai lembaga intermediasi antara bank dan masyarakat, yaitu menghimpun dana dari masyarakat dan disalurkan kepada masyarakat untuk kegiatan yang dapat meningkatkan taraf hidup. Perbankan di Indonesia terbagi menjadi dua, yaitu bank syariah dan bank konvensional. Kedua jenis bank ini memiliki produk bank yang hampir sama, hanya berbeda pada sistem operasionalnya. Bank konvensional menggunakan sistem bunga, sedangkan bank syariah menerapkan sistem bagi hasil, Permata et al (2014).

Baik tidaknya kinerja suatu bank dapat dinilai dari rasio keuangannya.. Rasio adalah suatu alat yang dinyatakan dalam artian relatif maupun absolut untuk menjelaskan hubungan tertentu antara faktor satu dengan yang lainnya dari suatu laporan finansial. Salah satu rasio yang terpenting adalah rasio profitabilitas.

Pada dasarnya bank syariah sebagaimana bank konvensional, juga menyalurkan dana kepada masyarakat dalam bentuk pembiayaan, namun terdapat perbedaan mendasar dalam hal imbalan. Penentuan imbal hasil yang diisyaratkan dan pembiayaan yang disalurkan oleh bank syariah kepada nasabahnya semata mata didasarkan pada prinsip bagi hasil (profit sharing). Produk bank yang menerapkan sistem bagi hasil adalah pada pembiayaan modal kerja dan investasi dalam bentuk pembiayaan mudharabah dan musyarakah. Tingginya tingkat resiko yang dihasilkan oleh pembiayaan dengan skema mudharabah atau musyarakah 
dapat menimbulkan pembiayaan bermasalah atau Non Performing Financing (NPF) bagi bank syariah.

Penelitian ini bertujuan untuk menganalisis pengaruh Non Performing Financing pembiayaan mudharabah dan Non Performing Financing pembiayaan musyarakah terhadap profitabilitas bank umum syariah. Pentingnya penelitian ini dilakukan adalah untuk memberikan informasi kepada masyarakat mengenai kinerja bank umum syariah berdasarkan tingkat kesehatan bank sebagai indikator untuk menilai kualitas suatu bank.

\section{TINJAUAN PUSTAKA DAN KERANGKA PEMIKIRAN}

Bank Syariah adalah bank yang menjalankan kegiatan usahanya berdasarkan Prinsip Syariah dan menurut jenisnya terdiri atas Bank Umum Syariah dan Bank Pembiayaan Rakyat Syariah. Dalam Undang-undang No. 21 tahun 2008 pasal 1 dijelaskan pengertian bank umum syariah dan bank pembiayaan syariah. Bank Umum Syariah adalah bank syariah yang dalam kegiatannya memberikan jasa dalam lalu lintas pembayaran. Sedangkan Bank Pembiayaan Rakyat Syariah adalah bank syariah yang dalam kegiatannya tidak memberikan jasa dalam lalu lintas pembayaran.

Dalam khasanah internasional bank syariah sering disebut juga dengan Islamic Banking. Islamic Banking menurut Rivai dan Veithzal (2008) adalah bank yang beroperasi sesuai dengan prinsip - prinsip yang ada dalam ajaran Islam, berfungsi sebagai badan usaha yang menyalurkan dana dari dan kepada masyarakat, atau sebagai perantara keuangan. Prinsip Islam yang dimaksud adalah perjanjian berdasarkan hukum Islam antara bank, pihak lain untuk penyimpan dana dan atau pembiayaan kegiatan usaha.

\subsection{Pembiayaan}

Pembiayaan menurut Karim (2011:321) adalah transaksi penyediaan dana dan/atau barang serta fasilitas lainnya kepada mitra yang tidak bertentangan dengan Syariah dan Standar Akuntansi Perbankan Syariah. Pembiayaan merupakan pendanaan yang diberikan oleh suatu pihak untuk mendukung investasi yang telah direncanakan baik dilakukan sendiri maupun dilakukan oleh orang lain. Tujuan pembiayaan ini yaitu: (1) secara makro merupakan peningkatan ekonomi, tersedianya dana bagi peningkatan usaha, meningkatkan produktivitas, membuka lapangan kerja baru, dan terjadi distribusi pendapatan. (2) secara mikro merupakan upaya memaksimalkan laba, upaya meminimalkan resiko, pendayagunaan sumber ekonomi, penyaluran kelebihan dana, Muhammad (2005). Tujuan alokasi dana untuk mencapai tingkat profitabilitas yang cukup dan resiko yang rendah, serta mempertahankan kepercayaan masyarakat dengan menjaga posisi likuiditas tetap aman.

\section{a. Pembiayaan Mudharabah}

Mudharabah berasal dari kata dharb yang bermakna memukul atau berjalan. Memukul atau berjalan dalam hal ini di artikan sebagai proses sedangkan memukul (melangkahkan) kakinya dalam menjalankan usaha untuk mencapai keuntungan. Keuntungan yang diperoleh dari usaha kerja sama tersebut kemudian akan 
dibagikan sesuai kesepakatan yang tertuang dalam akad (kontrak), namun jika terjadi Kerugian dari usaha tersebut maka kerugian akan ditanggung oleh pemilik modal dengan asumsi kerugian tersebut terjadi bukan karena kesalahan/kelalaian mudharib. Jika terjadi kerugian, maka pemilik modal akan menderita kehilangan sebagian atau mungkin seluruh modalnya sedangkan pihak mudharib akan mengalami kerugian dari segi pengorbanan tenaga, pikiran, waktu, harga diri dan sebagainya. Akan tetapi, jika kerugian tersebut terjadi akibat kelalaian atau kecurangan pihak mudharib, maka ia harus bertanggung jawab atas kerugian tersebut.

Pengertian mudharabah dalam konsep pembiayaan mudharabah pada Lembaga Keuangan Syari'ah dalam Fatwa Dewan Syari'ah Nasional MUI No. 07/DSN-MUI/2000 tentang Pembiayaan Mudharabah (Qiradh) (Fatwa MUI 07/2000), yakni pembiayaan yang disalurkan Lembaga Keuangan Syariah (LKS) kepada pihak lain untuk usaha yang produktif, LKS bertindak sebagai Shaahibul Maal (pemberi dana) dan pengusaha sebagai Mudharib (Pengelola Usaha).

\section{b. Pembiayaan Musyarakah}

Pembiayaan musyarakah menurut MUI No. 08/DSN-MUI/IV/2000 adalah semua bentuk usaha yang melibatkan dua pihak atau lebih dimana mereka secara bersama - sama memadukan seluruh bentuk sumber daya baik berwujud maupun yang tidak berwujud.

Pembiayaan musyarakah menurut Karim (2011) adalah akad kerja sama yang terjadi di antara para pemilik modal untuk menggabungkan modal dan melakukan usaha secara bersama dalam suatu kemitraan, dengan nisbah pembagian hasil sesuai dengan kesepakatan, sedangkan kerugian ditanggung secara proporsional sesuai dengan kontribusi modal. Menurut Antonio (2001:90) pembiayaan musyarakah adalah kerja sama antara dua pihak atau lebih untuk suatu usaha tertentu dimana masing - masing pihak memberikan kontribusi dana dengan kesepakatan bahwa keuntungan dan resiko akan ditanggung bersama sesuai dengan kesepakatan. Pembiayaan musyarakah adalah pembiayaan dengan penyertaan modal, dimana dua atau lebih mitra berkontribusi untuk memberikan modal suatu investasi.

\subsection{Profitabilitas}

Profitabilitas adalah kemampuan perusahaan dalam menghasilkan laba dari asset yang dimiliki. Profitabilitas merupakan naiknya ekuitas dari transaksi yang sifatnya insidentil dan bukan kegiatan utama entitas dan dari transaksi kejadian lainnya yang mempengaruhi entitas selama satu tahun periode tertentu kecuali yang berasal dari hasil atau investasi dan pemilik.

Indikator yang biasa digunakan untuk mengukur profitabilitas bank adalah ROE (Return On Equity) yaitu rasio yang menggambarkan besarnya kembalian atas total modal untuk menghasilkan keuntungan, dan ROA (Return On Assets) adalah rasio yang menunjukkan kemampuan manajemen bank dalam menghasilkan laba dari pengelolaan aset yang dimiliki. Tingkat profitabilitas bank syariah di Indonesia yang terbaik diukur dari rasio laba terhadap aset (ROA) termasuk untuk Unit Usaha Syariah. ROA digunakan untuk mengukur profitabilitas karena Bank Indonesia 
sebagai pembina dan pengawas perbankan lebih mengutamakan nilai profitabilitas suatu bank, diukur dengan aset yang dananya sebagian besar dana simpanan masyarakat.

\subsection{Pembiayaan Bermasalah atau Non Performing Financing (NPF)}

Non Performing Financing (NPF) atau pembiayaan bermasalah merupakan salah satu indikator kunci untuk menilai kinerja bank. Pembiayaan bermasalah adalah kredit yang pembayaran angsuran pokok dan/atau bunganya lewat 90 hari setelah jatuh tempo, atau pembiayaan yang pembayarannya secara tepat waktu sangat diragukan. NPF secara luas didefinisikan sebagai suatu pembiayaan dimana pembayaran yang dilakukan tersendat - sendat dan tidak mencukupi kewajiban minimal yang ditetapkan sampai dengan kredit yang sulit untuk dilunasi atau bahkan tidak dapat ditagih, Hadiyati (2013).

\subsection{KERANGKA PEMIKIRAN}

Keterkaitan antara resiko dalam pembiayaan yang berkorelasi dengan Non Performing Financing dan berpengaruh terhadap naik turunnya profitabilitas bank syariah sudah banyak dilakukan. Non Performing Financing merupakan indikator yang digunakan untuk mengukur kerugian akibat resiko pembiayaan. Semakin tinggi Non Performing Financing maka, semakin rendah profitablitas pada bank syariah.

Penelitian yang dilakukan oleh Firdaus (2008) menyebutkan bahwa secara simultan dan parsial terdapat pengaruh negatif resiko pembiayaan mudharabah maupun pembiayaan musyarakah terhadap profitabilitas bank syariah. Hadiyati (2013) menyatakan bahwa secara simultan variabel Non Performing Financing pembiayaan mudharabah dan pembiayaan musyarakah berpengaruh signifikan terhadap profitabilitas.

Penelitian selanjutnya oleh Fitriyani (2013) menyimpulkan bahwa tingkat resiko pembiayaan musyarakah berpengaruh negatif terhadap profitabilitas yang diukur dengan menggunakan ROA. Rochmatika (2012) yaitu hasil penelitian menunjukkan bahwa secara parsial pembiayaan bagi hasil berpengaruh negatif terhadap profitabilitas.

Berdasarkan Uraian diatas maka hipotesis dalam penelitian ini dapat dirumuskan sebagai berikut:

$\mathrm{H} 1$ : non performing financing pembiayaan mudharabah dan non performing financing pembiayaan musyarakah berpengaruh terhadap profitabilitas pada Bank Umum Syariah.

$\mathrm{H} 2$ : non performing financing pembiayaan mudharabah berpengaruh negatif terhadap profitabilitas pada Bank Umum Syariah.

H3 : non performing financing pembiayaan musyarakah berpengaruh negatif terhadap profitabilitas pada Bank Umum Syariah. 


\section{METODE PENELITIAN}

\subsection{Populasi Dan Sampel}

Populasi yang digunakan dalam penelitian ini adalah seluruh Bank Umum Syariah (BUS) di Indonesia. Sampel dalam penelitian ini adalah beberapa Bank Umum Syariah (BUS) Indonesia pada periode 2009 - 2013.Teknik pengambilan sampel dalam penelitian ini yaitu teknik purposive sampling, dimana sampel yang dipilih secara cermat dengan mengambil objek penelitian yang selektif dan mempunyai ciri yang spesifik.

Adapun kriteria pemilihan sampel adalah sebagai berikut :

a. Bank Umum Syariah (BUS) tersebut beroperasi dan mengeluarkan laporan keuangan tahunan pada periode penelitian 2009 sampai dengan 2013.

b. Data yang dibutuhkan berkaitan dengan variabel yang diteliti tersedia pada 2009 sampai dengan 2013.

\subsection{Variabel dan Definisi Operasional Variabel}

a. Variabel Independen( $X)$

1). Non Performing Financing Pembiayaan Mudharabah

Non Performing Financing adalah perbandingan besarnya jumlah pembiayaan bermasalah terhadap total pembiayaan yang diberikan oleh bank. Pembiayaan mudharabah adalah akad kerja sama antara dua pihak, dimana pihak pertama menyediakan seluruh modal (shahibul maal) dan pihak lain menjadi pengelola modal (mudharib), Antonio (2001:95). NPF pembiayaan mudharabah dihitung berdasarkan pembiayaan mudharabah bermasalah dibandingkan dengan total pembiayaan mudharabah yang diukur dengan menggunakan satuan persen, Fahrul (2012) dengan rumus sebagi berikut :

NPF Pembiayaan Mudharabah $=\frac{\text { Pembiayaan Mudharabah Bermasalah }}{\text { Total Pembiayaan Mudharabah }} \times 100 \%$

\section{2). Non Performing Financing Pembiayaan Musyarakah}

Non Performing Financing adalah perbandingan besarnya jumlah pembiayaan bermasalah terhadap total pembiayaan yang diberikan oleh bank. Pembiayaan musyarakah adalah akad kerja sama yang terjadi di antara para pemilik modal untuk menggabungkan modal dan melakukan usaha secara bersama dalam suatu kemitraan, dengan nisbah pembagian hasil sesuai dengan kesepakatan, sedangkan kerugian ditanggung secara proporsional sesuai dengan kontribusi modal, Karim (2011). NPF pembiayaan musyarakah dihitung berdasarkanpembiayaan musyarakah bermasalah dibandingkan dengan total pembiayaan musyarakah yang diukur dengan menggunakan satuan persen, Fahrul (2012) dengan rumus sebagai berikut :

NPF Pembiayaan Musyarakah $=\frac{\text { PembiayaanMusyarakahBermasalah }}{\text { Total Pembiayaan Musyarakah }} \times 100 \%$ 


\section{b. Variabel Dependen ( $Y$ )}

Variabel dependen dalam penelitian ini adalah profitabilitas bank syariah yang diproksikan dengan Return On Assets (ROA). Return On Assets (ROA) adalah rasio yang digunakan untuk mengukur kemampuan manajemen bank dalam menghasilkan laba bersih setelah pajak dibandingkan dengan total asset. Pengukuran dalam rasio ini menggunakan satuan persen, Permata, et al (2014) dengan rumus sebagai berikut :

Return On Assets $=\frac{\text { Laba Bersih Setelah Pajak }}{\text { Total Asset }} \times 100 \%$

\subsection{Alat Analisis}

Analisis yang digunakan dalam penelitian ini adalah regresi berganda dengan persamaan regresi sebagai berikut:

Keterangan :

$$
\text { Pro }=\alpha+\beta \text { I NPF PMud }+\beta 2 \text { NPF PMus }+\varepsilon
$$

a

$=$ Konstanta

$\beta I, 2$

= Koefisien Regresi

NPF PMud = Non Performing Financing Pembiayaan Mudharabah

NPF PMus = Non Performing Financing Pembiayaan Musyarakah

Pro $\quad=$ Profitabilitas

$\varepsilon \quad=$ Error

\subsection{Pengujian Hipotesis}

Uji hipotesis yang digunakan dalam penelitian ini adalah uji f untuk uji simultan dan uji t untuk uji parsial.

\section{HASIL DAN PEMBAHASAN}

\subsection{Analisis Regresi Linier Berganda}

Pengujian hipotesis dilakukan dengan menggunakan analisis regresi berganda yang bertujuan untuk mengetahui seberapa besar pengaruh NPF pembiayaan mudharabah dan NPF pembiayaan musyarakah dan tingkat profitabilitas sebagai berikut :

Tabel 1. Uji Regresi Linier Berganda

\section{Coefficients $^{\mathrm{a}}$}

\begin{tabular}{|l|l|r|}
\hline \multirow{2}{*}{ Model } & \multicolumn{2}{|c|}{$\begin{array}{l}\text { Unstandardized } \\
\text { Coefficients }\end{array}$} \\
\cline { 2 - 3 } & $\mathrm{B}$ & \multicolumn{1}{c|}{ Std. Error } \\
\hline 1 (Constant) & 1.281 & .219 \\
\hline
\end{tabular}




\begin{tabular}{l|r|r|} 
NPFPMud & .018 & .007 \\
NPFPMus & -.031 & .043 \\
\hline
\end{tabular}

Sumber : Lampiran 5

Berdasarkan tabel tersebut dapat disusun persamaan regresi sebagai berikut:

$\mathrm{PRO}=1,281+0,018 \mathrm{NPF}$ PMud - 0,031NPF PMus $+e$

Adapun interpretasi dari persamaan regresi tersebut adalah:

$\alpha=1,281$ artinya jika variabel NPF PMud dan NPF PMus bernilai nol, maka profitabilitas bank umum syariah sebesar 1,281 persen.

$\beta_{1}=0,018$ artinya apabila NPF PMud bertambah 1 persen maka, profitabilitas bank umum syariah akan meningkat sebesar 0,018 persen dengan asumsi variabel lain bernilai konstan.

$\beta_{2}=-0,31$ artinya apabila NPF PMus bertambah 1 persen maka, profitabilitas bank umum syariah akan menurun sebesar 0,31 persen dengan asumsi variabel lain bernilai konstan.

Hasil uji simultan ( Uji f)

Tabel 2. Hasil Uji Simultan

ANOVA $^{\text {b }}$

\begin{tabular}{|l|r|r|}
\hline Model & F & Sig. \\
\hline 1 Regression & 3.816 & $.033^{\mathrm{a}}$ \\
Residual & & \\
Total & & \\
\hline
\end{tabular}

Sumber : Lampiran 5

Berdasarkan tabel 1 di atas, hasil uji simultan menunjukkan bahwa nilai $F_{\text {hitung }}>$ $F$ tabel, dengan nilai $F$ hitung sebesar 3,816 dan nilai $F_{\text {tabel }}$ sebesar 3,32. Sehingga, hipotesis pertama yang menyatakan bahwa Non Performing Financing pembiayaan mudharabah dan Non Performing Financing pembiayaan musyarakah berpengaruh secara simultan terhadap profitabilitas bank umum syariah diterima.

Tabel 3. Hasil Uji Parsial ( Uji t )

Coefficients $^{a}$

\begin{tabular}{|l|l|l|}
\hline Model & $\mathrm{t}$ & Sig. \\
\hline
\end{tabular}




\begin{tabular}{|l|r|r|}
\hline 1 (Constant) & 5.842 & .000 \\
& 2.499 & .018 \\
NPFPMud & -.734 & .468 \\
\hline
\end{tabular}

Sumber : Lampiran 5

Berdasarkan tabel 3 di atas, dapat dijelaskan hasil dari pengujian secara parsial (individu) sebagai berikut:

Untuk variabel Non Performing Financing pembiayaan mudharabah nilai thitung sebesar 2,499 $>-t_{\text {tabel }}$ sebesar $-1,697$. Meskipun $t_{\text {hitung }}$ lebih besar dari $t_{\text {tabel }}$ dengan nilai signifikansi kurang dari 0,05 tetapi, arah koefisien regresi positif sehingga hipotesis kedua yang menyatakan bahwa Non Performing Financing pembiayaan mudharabah berpengaruh negatif terhadap profitabilitas ditolak.

Penelitian ini sejalan oleh Rochmanika (2008) yang menyatakan NPF berpengaruh positif terhadap profitabilitas yang diproksikan dengan Return On Asset dikarenakan meningkatnya pembiayaan yang disalurkan sehingga mengakibatkan banyaknya nasabah yang yang tidak mengembalikan pembiayaan karena terganggu kelancaran usaha yang disebabkan oleh situasi ekonomi yang buruk dan tidak adanya pengawasan dari pihak internal bank syariah. Berbeda dengan Hadiyati (2013) yang menyatakan bahwa NPF pembiayaan mudharabah berpengaruh negatif terhadap profitabilitas bank umum syariah.

Untuk variabel Non Performing Financing pembiayaan musyarakah nilai thitung sebesar $-734>-t_{\text {tabel }}$ sebesar $-1,697$ dengan nilai signifikan 0,468 sehingga hipotesis ketiga yang menyatakan bahwa Non Performing Financing pembiayaan musyarakah berpengaruh negatif terhadap profitabilitas ditolak. Tetapi, meskipun tidak berpengaruh negatif nilai koefisien regresi dalam penelitian ini juga bertanda negatif.

Hal ini didukung oleh penelitian Hadiyati (2013) yang menyatakan bahwa NPF pembiayaan musyarakah tidak berpengaruh terhadap profitabilitas bank syariah dikarenakan tidak sesuai dengan konsep profitabilitas suatu bank adalah kualitas pembiayaan yang diberikan dan pengembaliannya, dengan kata lain besarnya resiko pengembalian pembiayaan akan mempengaruhi tingkat profitabilitas suatu bank. Jika tingkat NPF atau pembiayaan bermasalah tinggi maka profitabilitas akan mengalami penurunan sedangkan, jika tingkat NPF rendah maka profitabilitas akan mengalami kenaikan.

\section{SIMPULAN DAN SARAN}

Berdasarkan hasil analisis data dan pembahasan diatas, maka dapat ditarik beberapa kesimpulan, antara lain:

1. Non Performing Financing pembiayaan mudharabah dan Non Performing Financing pembiayaan musyarakah berpengaruh secara simultan terhadap profitabilitas. Hal ini ditunjukkan dengan nilai $F_{\text {hitung }} 3,816>F_{\text {tabel }} 3,32$.

2. Non Performing Financing pembiayaan mudharabah tidak berpengaruh negatif terhadap profitabilitas bank umum syariah namun arahnya menunjukkan positif. Hal ini ditunjukan dengan nilai $t_{\text {hitung }}>t_{\text {tabel }}$ yaitu $2,499>-$ 1,697 dengan nilai signifikansi 0,018 kurang dari 0,05. 
3. Non Performing Financing pembiayaan musyarakah tidak berpengaruh terhadap profitabilitas bank umum syariah. Hal ini ditunjukan dengan nilai $t_{\text {hitung }}>t_{\text {tabel }}$ yaitu $\quad-734>-1,697$.

\section{Saran}

Berdasarkan kesimpulan yang telah dijelaskan di atas, maka ada beberapa saran untuk pengambilan kebijakan bagi pihak bank dan peneliti selanjutnya, yaitu sebagai berikut :

1. Pihak perbankan syariah harus terus meningkatkan kualitas pengelolaannya mengingat kedua jenis produk pembiayaan bagi hasil ini merupakan ciri khas produk pembiayaan bank syariah.

2. Pihak perbankan syariah harus lebih meningkatkan prinsip kehati - hatian sehingga dapat meminimalisasi NPF, dimana dalam pengembangan produk produk yang ada harus lebih inovatif dengan tetap memperhatikan prinsip prinsip syariah.

3. Bagi penelitian selanjutnya hendaknya dapat diarahkan kepada bagaimana tingkat resiko pembiayaan mempengaruhi likuiditas, solvabilitas dan rentabilitas bank umum syariah.

\section{DAFTAR PUSTAKA}

Antonio, Muhammad Syafi'i. 2001. Bank Syariah Dari Teori ke Praktek. Jakarta: Gema Insani bekerjasama dengan Tazkia Cendekia.

Ascarya. 2011. Akad dan Produk Bank Syariah. Jakarta: PT. Raja Grafindo Persada. Bintang, Andika. (2013). "Analisis pengaruh non performing financing pembiayaan murabahah, pembiayaan mudharabah, dan pembiayaan musyarakah terhadap profitabilitas dengan mnggunakan pendekatan Return On Asset (ROA) pada bank umum syariah". Skripsi Fakultas Ekonomi Universitas Pembangunan Nasional "Veteran"

Bustomi, Ahmad. 2005. "Pengaruh kredit bermasalah terhadap tingkat profitabiltas bank, studi kasus bank konvensional yang telah go public". Skripsi Fakultas Ekonomi dan Bisnis Universitas Padjajaran Bandung.

Dewan Syariah Nasional-Majelis Ulama Indonesia. 2000. Fatwa No. 07/DSNMUl/2000 tentang pembiayaan mudharabah. Jakarta.

Dewan Syariah Nasional-Majelis Ulama Indonesia. 2000. Fatwa No. 08/DSN$\mathrm{MUI} / 2000$ tentang pembiayaan musyarakah. Jakarta.

Fahrul, et al. 2012. "Pengaruh tingkat risiko pembiayaan musyarakah dan pembiayaan murabahah terhadap tingkat profitabilitas Bank Syariah". Studi Pada Bank Aceh Syariah Cabang Banda Aceh. Jurnal Akuntansi, November 2012, Hal. 76-85. Volume 2, No. 1. ISSN 2302-0164.

Firdaus, Hamdi. 2008. "Pengaruh Risiko Pembiayaan Mudharabah dan Pembiayaan Musyarakah Terhadap Profitabilitas Bank Syariah". Skripsi Fakultas Ekonomi dan Bisnis Universitas Padjajaran Bandung.

Fiswara, 2008. "Pengaruh tingkat non performing financing pembiayaan mudharabah dan pembiayaan musyarakah terhadap tingkat profitabilitas (Return On Assets) pada Bank Syariah (Studi Kasus Pada PT. Bank Syariah Mandiri)". Skripsi Fakultas Bisnis dan Manajemen Univertas Widyatama. 
Ghazali, Imam. 2013. Aplikasi Analisis Multivariate dengan Program IBM SPSS 21Update PLS Regresi. Badan Penerbit. UNDIP.

Hadiyati, Puji. 2013. "Pengaruh Non Performing Financing Pembiayaan Mudharabah dan Pembiayaan Musyarakah Pada Bank Muamalat Indonesia". E-Jurnal Manajemen dan Bisnis, Oktober 2013, Vol 1. No.1. ISSN 2355-0244.

Karim, Adiwarman A. 2011. Bank Islam Analisis Fiqih dan Keuangan. Jakarta: PT Raja Grafindo Persada.

Rochmawati, 2012. "Pengaruh pembiayaan jual beli, pembiayaan bagi hasil, dan rasio non performing financing terhadap profitabilitas bank umum syariah di Indonesia.

Muhammad, 2005. Manajemen Pembiayaan Bank Syariah. Yogyakarta: UPP AMP YKPN.

Muhammad, 2013. "Analisis pengaruh suku bunga, inflasi, CAR, BOPO, NPF terhadap profitabilitas Bank Syariah". Diponegoro Jurnal of Accounting, 2013, Halaman 1-10. Volume 2. Nomor 2. ISSN 2337-3792.

Permata, et al. 2014."Analisis Pengaruh Pembiayaan Mudharabah dan Musyarakah Terhadap Tingkat Profitabilitas (Return On Equity)". Jurnal Administrasi Bisnis (JAB) Vol. 12 No. 1 Juli 2014.

Rivai, Veithzal, et al. 2012. Banking and Finance (Dari Teori ke Praktik Bank dan Keuangan Syariah Sebagai Solusi dan Bukan Alterntif). Edisi Pertama. Yogyakarta: BPFE.

Rochmanika, Ridha, et al. 2012. Pengaruh Pembiayaan Jual Beli, Pembiayaan Bagi Hasil, dan Rasio Non Performing Financing terhadap Profitabilitas Bank Umum Syariah di Indonesia. Jurnal Fakultas Ekonomi dan Bisnis Universitas Brawijaya

Siamat, Dahlan. 2005. Manajemen Lembaga Keungan. Edisi Kelima. Jakarta: Lembaga Penerbit FE UI.

Sri, Maryana Rina. 2005. "Pengaruh tingkat risiko pembiayaan terhadap tingkat profitabilitas Bank Syariah, penelitian pada Bank Muamalat Indonesia Tbk".

UU Perbankan No. 21 tahun 2008 tentang Perbankan Syariah.

Wulan Sari, Dita. 2013. "Pengaruh Pembiayaan Jual Beli, Pembiayaan Bagi Hasil, FDR (Financing To Deposit Ratio) dan NPF (Non Performing Financing) Terhadap Profitabilitas Bank Umum Syariah". Skripsi Fakultas Ekonomika dan Bisnis Universitas Diponegoro Semarang.

www.bi.go.id. 